\title{
Biological management of foliar diseases in organic rice cultivation
}

\author{
MALLIKARJUN KENGANAL ${ }^{1 *}$, YUSUF ALI NIMBARAGI ${ }^{2}$ AND G. S. GURUPRASD ${ }^{3}$ \\ ${ }^{1}$ Department of Plant Pathology, University of Agricultural Sciences, RAICHUR (KARNATAKA) INDIA \\ ${ }^{2}$ Agricultural Extension Education Centre, KOPPAL (KARNATAKA) INDIA \\ ${ }^{3}$ AICRP on Rice, Agricultural Research Station, GANGAVATI (KARNATAKA) INDIA
}

\section{ARITCLE INFO}

$\begin{array}{ll}\text { Received } & : 03.07 .2017 \\ \text { Revised } & : 05.09 .2017 \\ \text { Accepted } & : 17.09 .2017\end{array}$

KEY WORDS :

Organic rice, Disease management, Biointensive, Pseudomonas

fluorescens, Neem oil
*Corresponding author: Email : mallikarjun_nss@ rediffmail. com

\begin{abstract}
:
Organic rice has high demand due to increased health awareness among the consumers about ill effects of high pesticide residues in food commodities which are integral part of every day. The premium price for organic produces and low cost inputs are other attraction among the organic farmers who are keen to cultivate organic rice. In order to overcome the losses in rice due to diseases, suitable non-chemical management strategies are need of the hour. The current experiment was conducted to identify the biointensive rice diseases management opportunities suitable for organic rice growers. Bio inputs such as Beejamrutha, Pseudomonas fluorescens, Panchagavyya, cow urine, vermiwash and Neem oil were tested in ten different treatments over two years on organically maintained plot. Seed treatment of rice with P. fluorescens, @ $5 \mathrm{~g} / \mathrm{kg}$ followed by dipping of 30days old seedlings in P. fluorescens ( $0.5 \%$ ) solution for 30 minutes followed by topical application of $P$. fluorescens $5 \mathrm{~g} / \mathrm{l}+\mathrm{Neem}$ oil $5 \mathrm{ml} / \mathrm{l}$ at an interval of 15 days beginning from first application at 15 days after transplanting had the lowest incidence of diseases in both the years. The pooled analysis concluded this treatment most effective with lowest incidence of leaf blast (23.27\%), bacterial leaf blight (21.36\%) and sheath blight (28.38\%), respectively compared to control which had 39.31 per cent leaf blast, 37.31 per cent of bacterial leaf blast and 45.78 per cent of sheath blight. This treatment also recorded highest grain yield of $6800 \mathrm{~kg} / \mathrm{h}$ and $7833 \mathrm{~kg} / \mathrm{h}$ during 2014 and 2015 , respectively. The average yield recorded was $7316 \mathrm{~kg} / \mathrm{ha}$ with a cost benefit ratio of 2.11. In control, two years average yield was $3740 \mathrm{~kg} / \mathrm{h}$ with the cost benefit ratio of 1.49 which concludes that best treatment recorded has more promising returns with multiple benefits. Organic rice growers can easily adopt with low cost and no dependence on chemical pesticides. Use of $P$. fluorescens and Neem oil had neither residue problem nor mode of application making them ideal choice for biointensive management of rice diseases.
\end{abstract}

How to view point the article : Kenganal, Mallikarjun, Nimbaragi, Yusuf Ali and Guruprasd, G.S. (2017). Biological management of foliar diseases in organic rice cultivation. Internat. J. Plant Protec., 10(2) : 404-409, DOI : 10.15740/HAS/IJPP/10.2/404-409. 